\title{
Austenite-Bainite Transformation Kinetics in Austempered AISI 5160 Steel
}

\author{
Xue Han, MA, \\ Gary Barber, PhD, \\ Zhenpu Zhang, $M A$, \\ Bingxu Wang, PhD, \\ Jian Zhu, PhD, \\ Jing Shi, MA, \\ Xichen Sun, PhD,
}

Oakland University and Fiat-Chrysler LLC, USA

Doi: 10.19044/esj.2018.v14n12p1 URL:http://dx.doi.org/10.19044/esj.2018.v14n12p1

\begin{abstract}
This research investigates the process of the formation of bainite in austempered 5160 steel. Steel bar samples were austenitized at $1128 \mathrm{~K}$ for 20 minutes followed by holding at various times from 10 seconds to 2 hours and isothermal temperatures from $561 \mathrm{~K}$ to $728 \mathrm{~K}$ to obtain a multi-phase matrix. Micro-hardness analysis and metallurgical optical microscopy were used to analyze the experimental results. Hardness results indicated that at the $561 \mathrm{~K}$, $589 \mathrm{~K}$, and $566 \mathrm{~K}$ isothermal temperatures for 5160 steel, lower bainite transformation occurred. However, from $644 \mathrm{~K}$ to $728 \mathrm{~K}$, upper bainite transformation was found from the steel. The formation of the bainitic phase in SAE 5160 steel was characterized using thermodynamic and kinetic theories.
\end{abstract}

Keywords: Material Science, formation of bainite, 5160 steel, isothermal temperatures

\section{Introduction}

SAE 5160 steel is a high carbon and chromium spring steel, which is commonly used by forgers. It has excellent toughness, outstanding ductility, high yield to tensile strength ratio, and a high level of shock resistance which make it a suitable spring steel for parts exposed to stress, vibration, and shock. SAE 5160 is used in the automotive field in applications, such as scrapers, equalizers, bumpers, and various heavy spring applications, especially for leaf 
springs. Since it has good impact resistance, it is also used for knives that need to hold an edge. To enhance the properties of 5160 steel, heat treatment processes are commonly used (Krishna et. al., 2013) such as austenitizing and austempering to produce bainite.

The bainite transformation has been investigated for several decades (Speer et. al., 2004, Grajcar et. al., 2014, Borgenstam et. al., 2012, DurandCharre, 2004, Bhadeshia, 1990, Bhadeshia et. al., 1980, Lawrynowicz, 2016, Takahashi, 2004) Generally, the process of bainite isothermal transformation is composed of two steps (Lawrynowicz, 2016, Soliman et. al., 2016, Zhou et. al., 2017): austenitizing and austempering. In the austenitizing step, steel is heated above the critical temperature and held until the austenite transformation is complete. For the austempering step, bainite is formed by an isothermal heat treatment and obtained from the decomposition of austenite, this process is called austempering (Krauss, 1990, Navarro-Lopez et. al., 2017). Martensite is typically also contained in the microstructure which is obtained from the residual austenite (Junior et. al., 2013).

Bainite is a non-lamellar mixture of ferrite and carbide. Due to the difference of carbide precipitates, it can be classified into upper bainite and lower bainite (Bhadeshia, 1992, Caballero et. al., 2004, Quidort et. al., 2001). Both are aggregates of small plates or laths of ferrite. The ferrite in upper bainite is free of precipitates. Carbide particles precipitate from the supersaturated bainitic ferrite for the lower bainite formation (Bhadeshia, 1992). There are several types of steel and cast iron for which the bainite transformation has been studied (Tomita et. al., 1993, Khan et. al., 1990, Saeidi et. al., 2009, Johnson et. al., 1993), however, the bainite transformations of 5160 steel from austenite at various austempering temperatures and times have not been fully investigated. Thus, this investigation is focused on a study of the process of the bainite transformation from austenite in austempered 5160 steel. The bainite transformation kinetics are discussed as well.

\section{Experimental Procedure Material}

The chemical composition of the 5160 steel is presented in Table 1. Rockwell hardness measurements were done and it was found that the asreceived 5160 steel hardness is $24 \mathrm{HRC}$.

Table 1: The chemical composition of 5160 steel (wt. \%)

\begin{tabular}{ccccccc}
\hline $\mathrm{C}$ & $\mathrm{Cr}$ & $\mathrm{Fe}$ & $\mathrm{Mn}$ & $\mathrm{P}$ & $\mathrm{Si}$ & $\mathrm{S}$ \\
\hline & & & & & & \\
$0.56-0.64$ & $0.7-0.9$ & $97.085-97.84$ & $0.75-1.0$ & $\leq 0.035$ & $0.15-0.3$ & $\leq 0.04$ \\
\hline
\end{tabular}

\section{Heat Treatment}

All the samples were cut into half disks with a diameter of $3 \mathrm{~cm}$ and a 
thickness of $0.7 \mathrm{~cm}$, Figure 1 shows the original microstructure of the specimens before heat treatment. It can be seen that the microstructure is primarily pearlite.

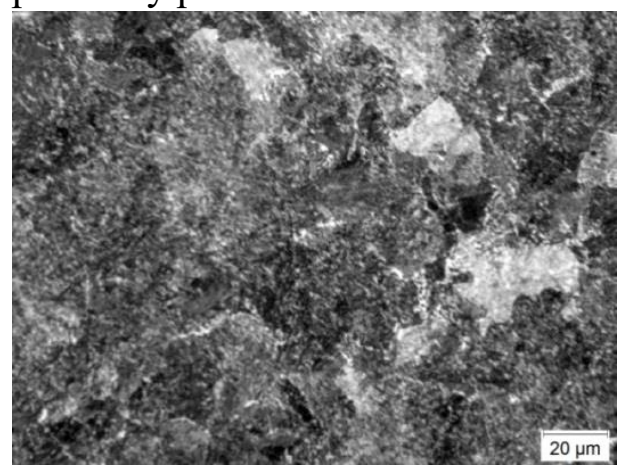

(a)

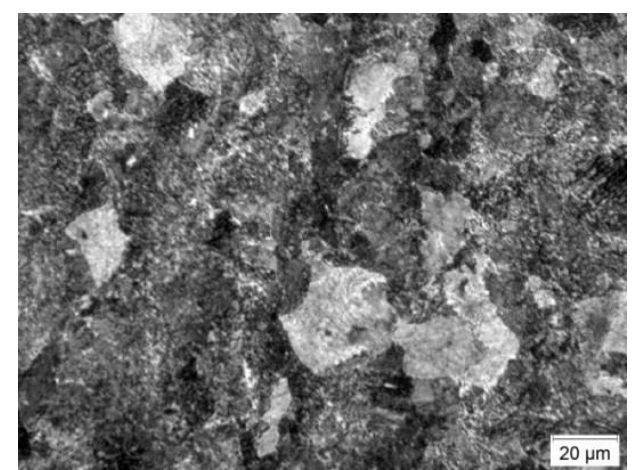

(b)

Fig.1 Microstructure of original specimen material: a) Longitudinal Section (500X), b) Transverse Section (500X).

To study the 5160 steel bainite transformation process, all the specimens were first austenitized and then austempered. The specimens were austenitized at $1128 \mathrm{~K}$ for 20 minutes, and then held at various austempering temperatures and different times. Seven different austempering temperatures of $561 \mathrm{~K}, 589 \mathrm{~K}, 617 \mathrm{~K}, 644 \mathrm{~K}, 672 \mathrm{~K}, 700 \mathrm{~K}$, and $728 \mathrm{~K}$ were utilized and holding times were $10 \mathrm{~s}, 15 \mathrm{~s}, 20 \mathrm{~s}, 30 \mathrm{~s}, 40 \mathrm{~s}, 45 \mathrm{~s}, 50 \mathrm{~s}, 60 \mathrm{~s}, 3 \mathrm{mins}, 5 \mathrm{mins}$, $10 \mathrm{mins}, 15 \mathrm{mins}, 30 \mathrm{mins}$, 1 hour, and 2 hours, respectively. The heat treatment process is shown in Figure 2. After finishing the two heat treatment steps, samples were removed from the salt bath and water quenched to room temperature. The high and low temperature furnaces are shown in Figure 3.

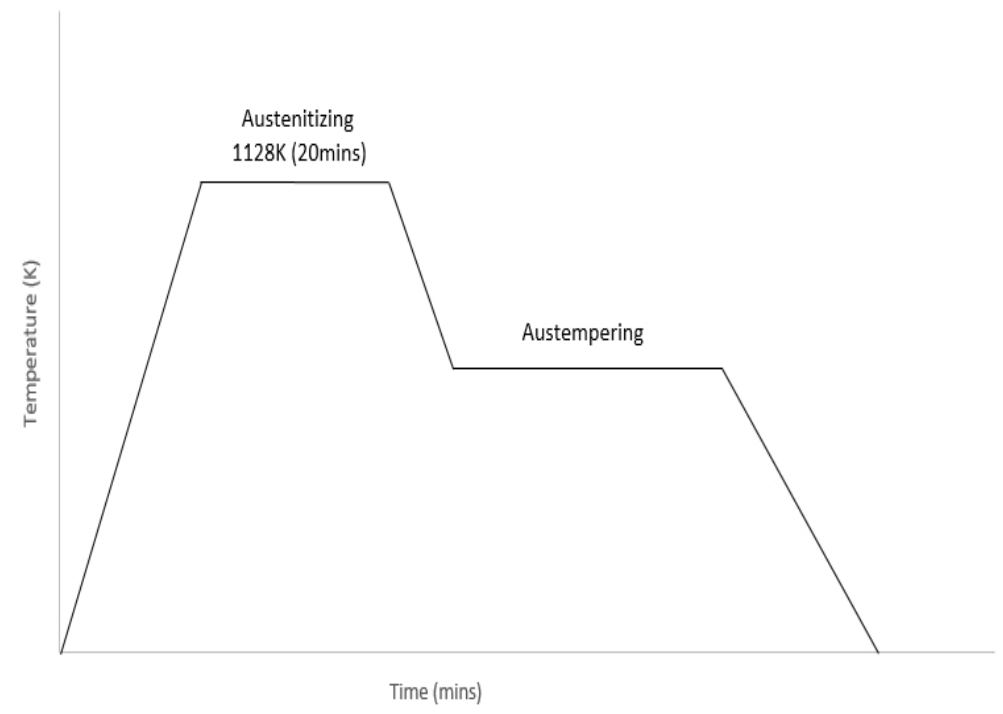


Fig.2 Heat Treatment Process

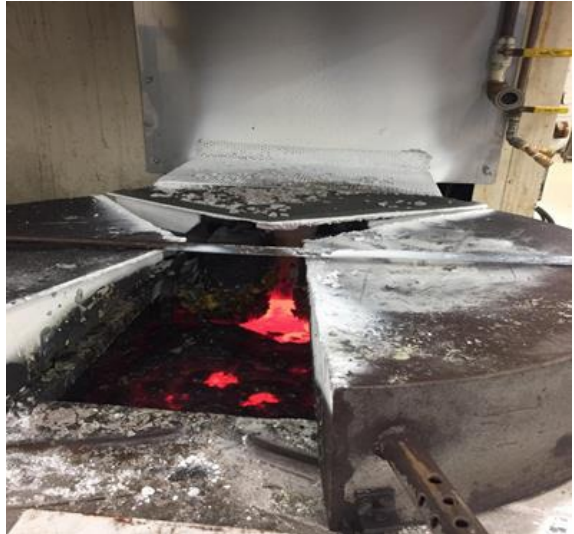

(a)

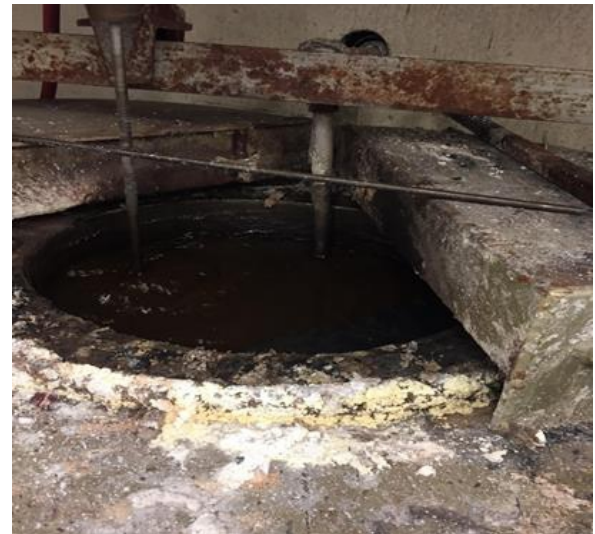

(b)

Fig. 3 Salt Bath Furnaces: a) High Temperature, b) Low Temperature

\section{Results}

\section{Microstructure of austempered 5160 steel}

The microstructures of the austempered specimens of 5160 steel austempered from $561 \mathrm{~K}$ to $728 \mathrm{~K}$ with various times are shown in Figure 4. All the austempering times and temperatures produced at least some bainite microstructure. The needle like structure (bainite) increases as the autempering time is increased. Bainite transformation is observed at three levels: beginning, medium, and finish. Since the upper bainite microstructure is coarser than lower bainite, it was observed that lower bainite is produced from $561 \mathrm{~K}$ to $617 \mathrm{~K}$, however, $672 \mathrm{~K}$ to $728 \mathrm{~K}$ produced upper bainite. Upper bainite and a small amount of lower bainite were observed at $644 \mathrm{~K}$. The fraction of martensite decreases with longer holding times.

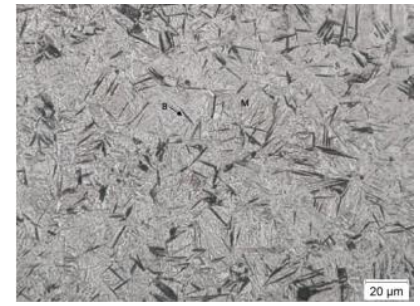

(a)

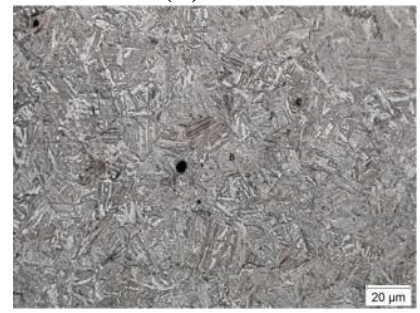

(c)

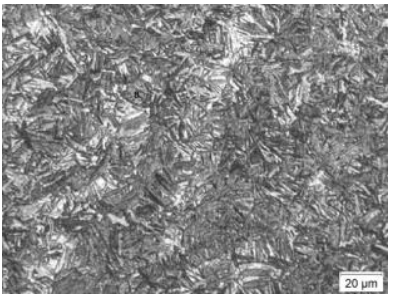

(b)

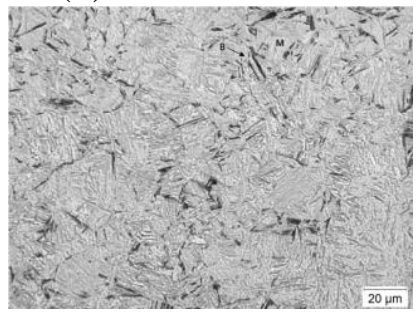

(d) 


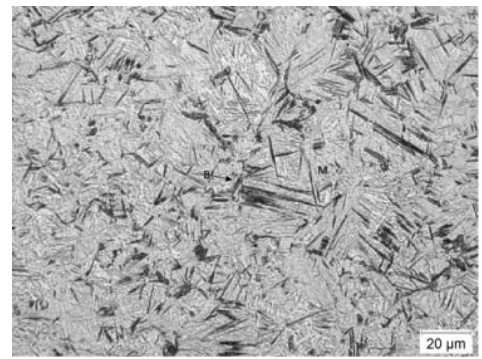

(e)

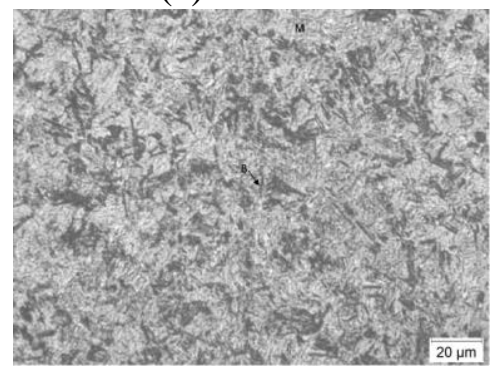

(g)

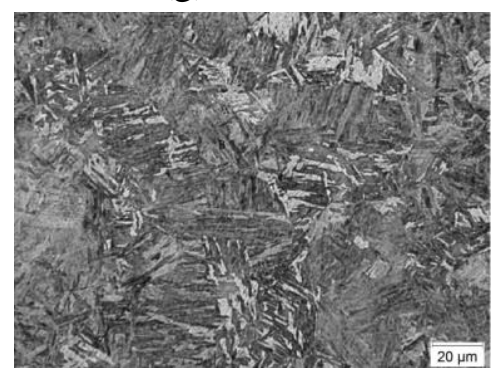

(i)

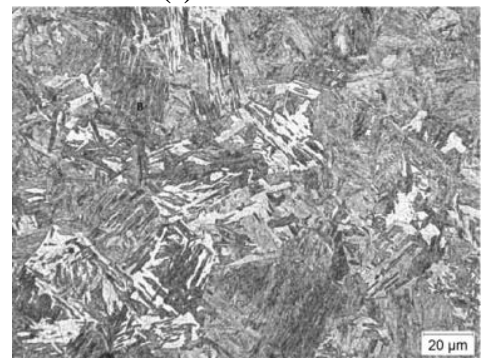

(k)

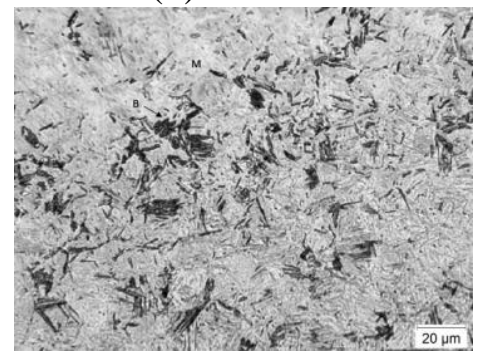

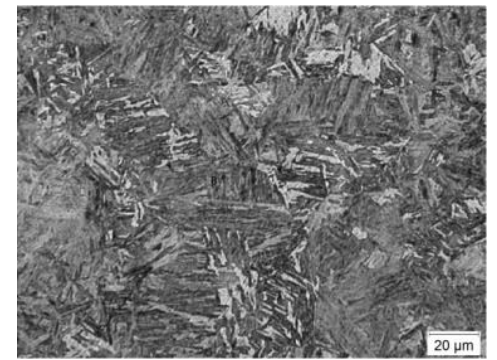

(f)

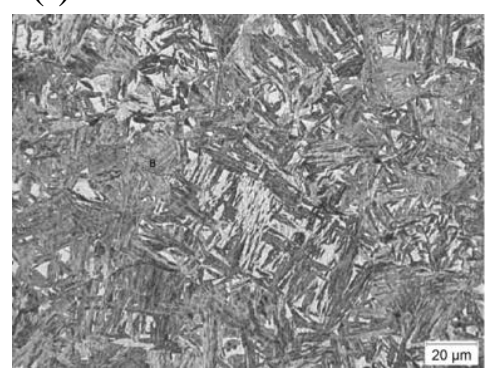

(h)

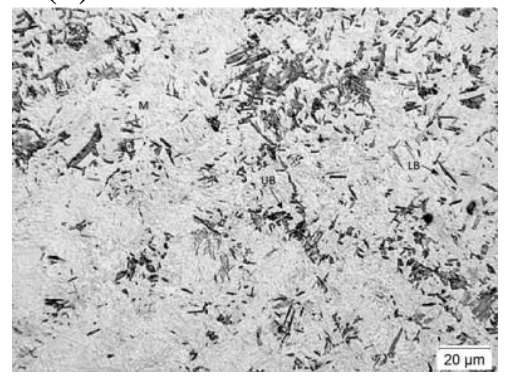

(j)

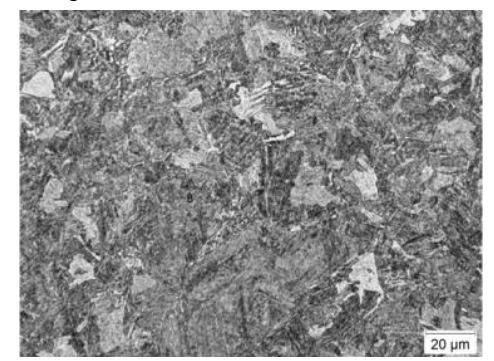

(1)

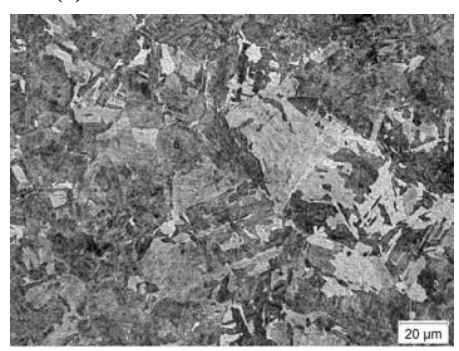


(m)

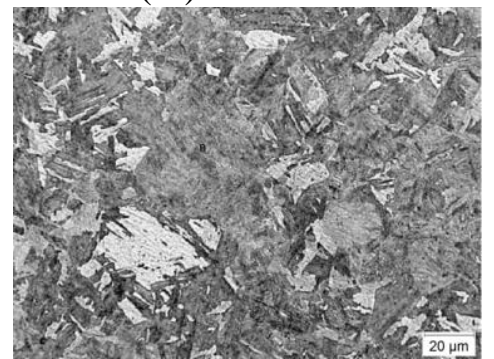

(o)

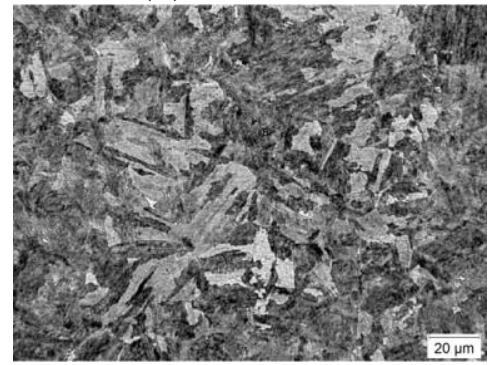

(q)

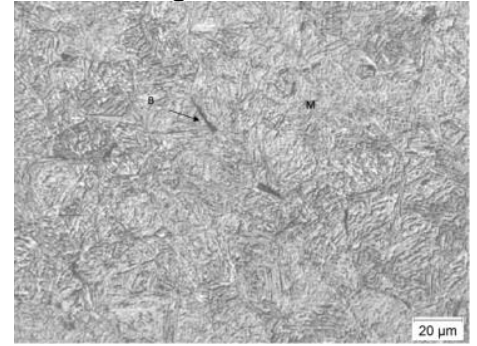

(s)

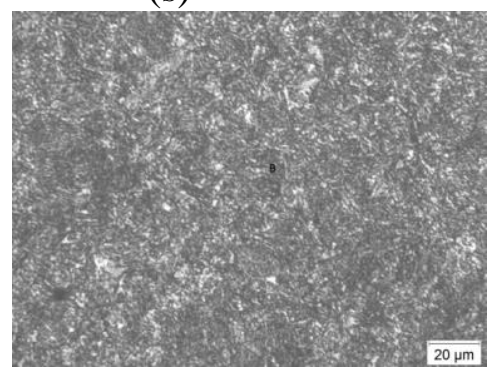

(u) (n)

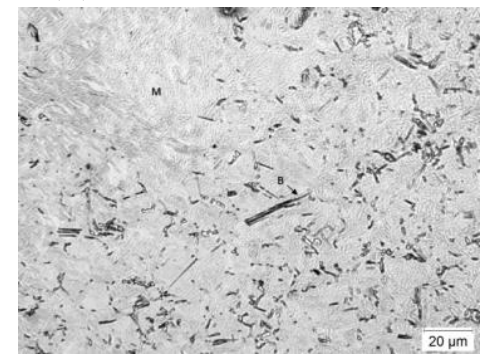

(p)

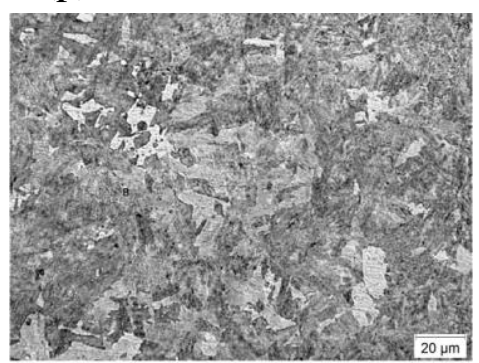

(r)

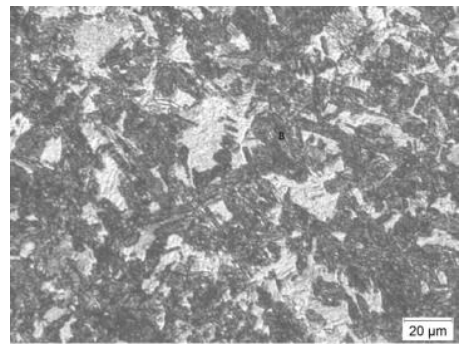

$(\mathrm{t})$

Fig. 4 Microstructure of 5160 steel at different temperatures with various austempering holding time: a) $561 \mathrm{~K}-3 \mathrm{mins}$, b) $561 \mathrm{~K}-15 \mathrm{mins}$, c) $561 \mathrm{~K}-120 \mathrm{mins}$, d) $589 \mathrm{~K}-30 \mathrm{~s}$, e) $589 \mathrm{~K}$ $-60 \mathrm{~s}$, f) $589 \mathrm{~K}-120 \mathrm{mins}$, g) $617 \mathrm{~K}-30 \mathrm{~s}$, h) $617 \mathrm{~K}-30 \mathrm{mins}$, i) $617 \mathrm{~K}-120 \mathrm{mins}$, j) $644 \mathrm{~K}-$ $30 \mathrm{~s}, \mathrm{k}$ ) $644 \mathrm{~K}-3 \mathrm{mins}$, 1) $644 \mathrm{~K}-120 \mathrm{mins}, \mathrm{m}) 672 \mathrm{~K}-20 \mathrm{~s}, \mathrm{n}) 672 \mathrm{~K}-3 \mathrm{mins}$, o) $672 \mathrm{~K}-$ $120 \mathrm{mins}$, p) $700 \mathrm{~K}-10 \mathrm{~s}$, q) $700 \mathrm{~K}-3 \mathrm{mins}$, r) $700 \mathrm{~K}-120 \mathrm{mins}$, s) $728 \mathrm{~K}-10 \mathrm{~s}$, t) $728 \mathrm{~K}-60 \mathrm{~s}$, u) $728 \mathrm{~K}-120 \mathrm{mins}$ 


\section{Hardness (HRC) Measurements}

Hardness was measured three times for each sample. The average hardness values are presented in Figure 5. Figure 5.a shows hardness with specimens containing lower bainite. Figure 5.b shows hardness of samples containing upper bainite from $672 \mathrm{~K}$ to $728 \mathrm{~K}, 644 \mathrm{~K}$ shows primarily upper bainite with a small amount of lower bainite. It can be seen that as the austempering temperature and holding time increase, all the hardness values decreased.

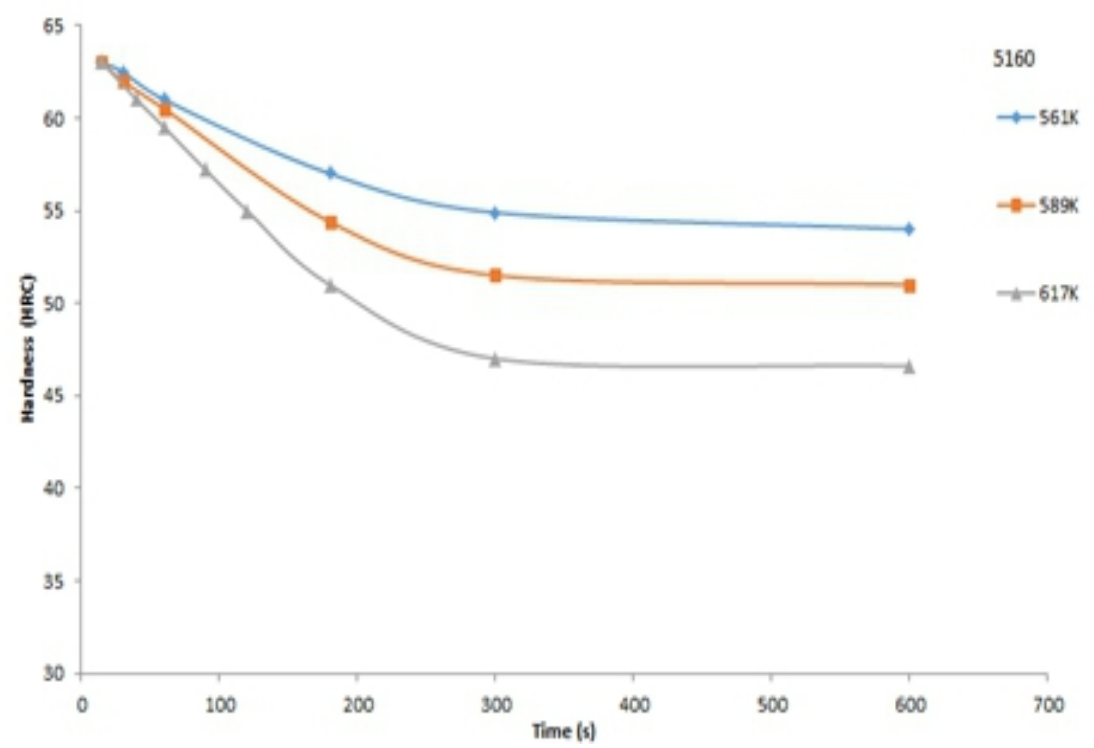

(a)

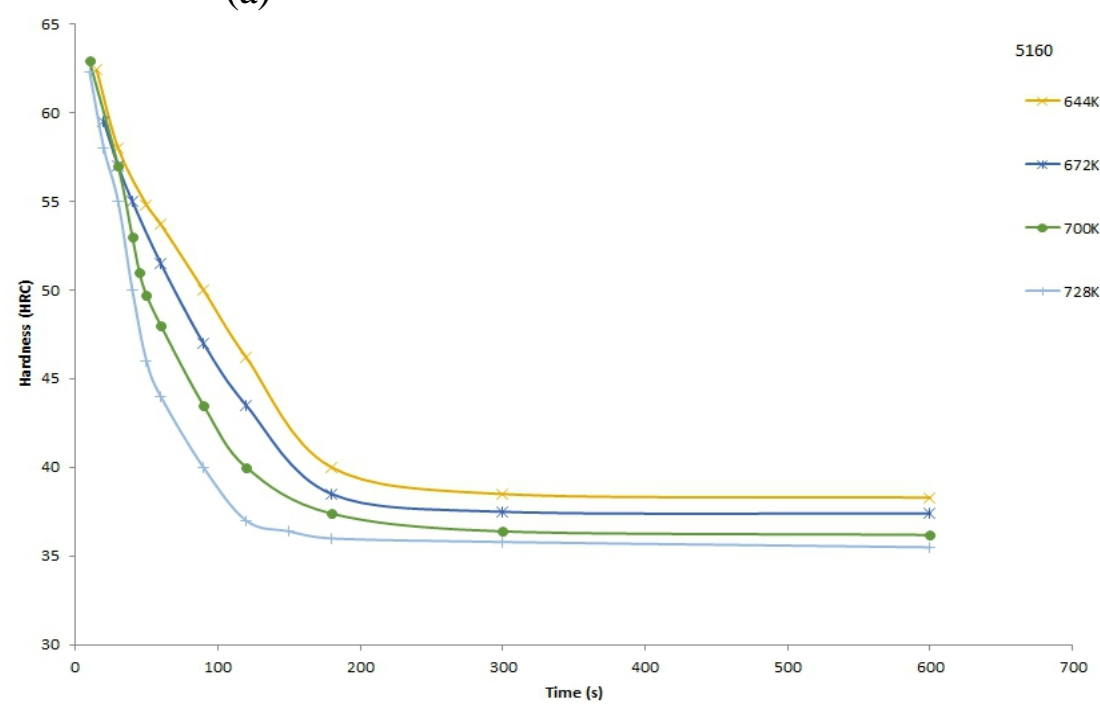

(b)

Fig.5 5160 material hardness obtaining with different austempering temperature and holding time: a) $561 \mathrm{~K}, 589 \mathrm{~K}, 617 \mathrm{~K}$, b) $644 \mathrm{~K}, 672 \mathrm{~K}, 700 \mathrm{~K}, 728 \mathrm{~K}$ 


\section{Transformation Kinetics}

The bainite transformation kinetics was studied using hardness analysis. It utilized the following function (Milosan, 2008, Ioan, 2014):

$$
X_{(t)}=\frac{H_{0}-H_{(t)}}{H_{0}-H_{f}} \times 100 \%
$$

Where: $X_{(t)}-$ The fraction of transformation;

$H_{0}$ - The initial hardness, which corresponds with the first bainite transformation beginning after a specific holding time;

$H_{(t)}$ - The hardness obtained after a holding time at the austempering temperature;

$H_{f}$ - The final hardness which corresponds with the last transformation of the bainitic reaction.

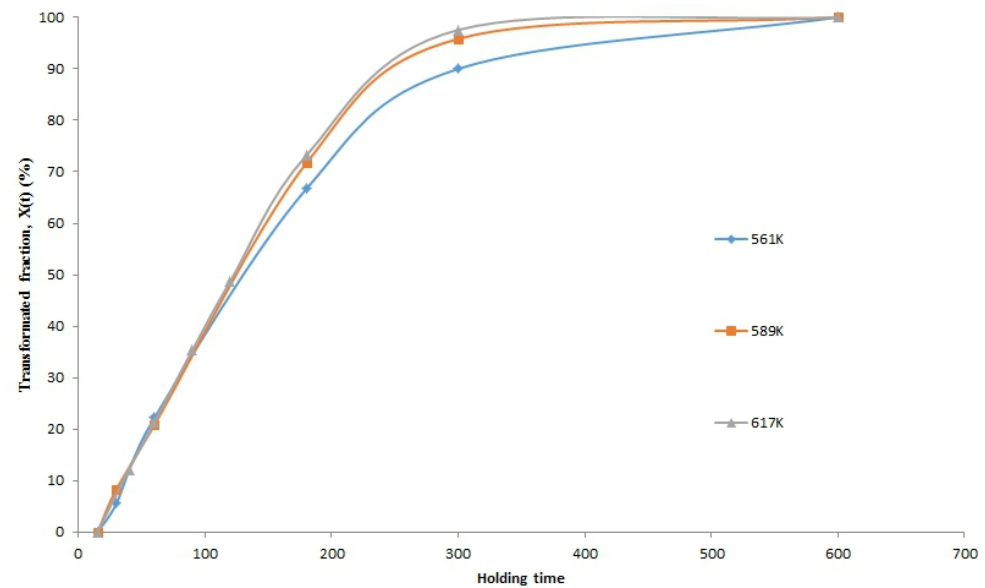

(a)

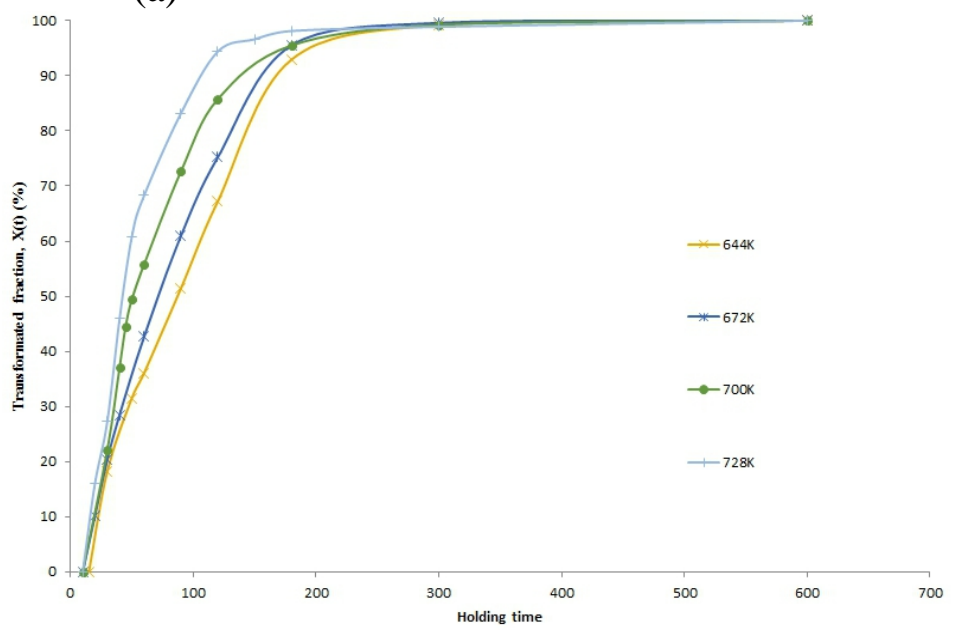

(b)

Fig.6 5160 Transformation Fraction: a) comparison among 561K, 589K, and 617K, b) comparison among $644 \mathrm{~K}, 672 \mathrm{~K}, 700 \mathrm{~K}$, and $728 \mathrm{~K}$ 
Figure 6 shows the bainite transformation fraction at different austempering temperatures. When comparing $561 \mathrm{~K}, 589 \mathrm{~K}$, and $617 \mathrm{~K}$, as the temperature increases for the same holding time, higher temperature results in faster transformation. Austempering temperatures of $644 \mathrm{~K}, 672 \mathrm{~K}, 700 \mathrm{~K}$, and 728K show a similar trend.

The "Avrami" equation is used to describe the relationship between the transformed fraction and different temperature at various times. The equation is as follows (Milosan, 2008, Ioan, 2014, Umemoto et. al., 1982, Bhadeshia, 1982):

$$
\mathrm{X}(\mathrm{t})=1-\exp \left(-\mathrm{k} t^{n}\right)
$$

Where: $X(t)$ - Transformation fraction at a certain time

$\mathrm{k}$ - Rate constant which depends on temperature

$\mathrm{n}$ - Slope of "Avrami" plot

The values of $\mathrm{k}$ and $\mathrm{n}$ can be determined by the following rearrangement of the "Avrami" equation (Milosan, 2008, Ioan, 2014):

$\log [-\log (1-X)]=(n \log k+\log \log e)+n \log t$

The $\log [-\log (1-X)]$ versus $\log t$ at different temperatures are shown in Figure 7.

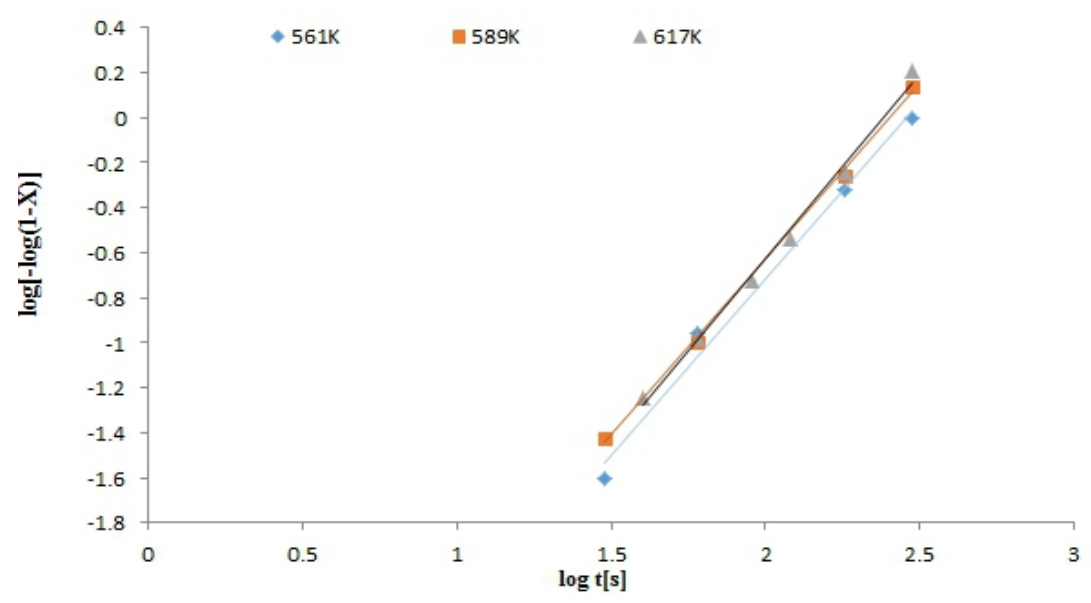

(a) 


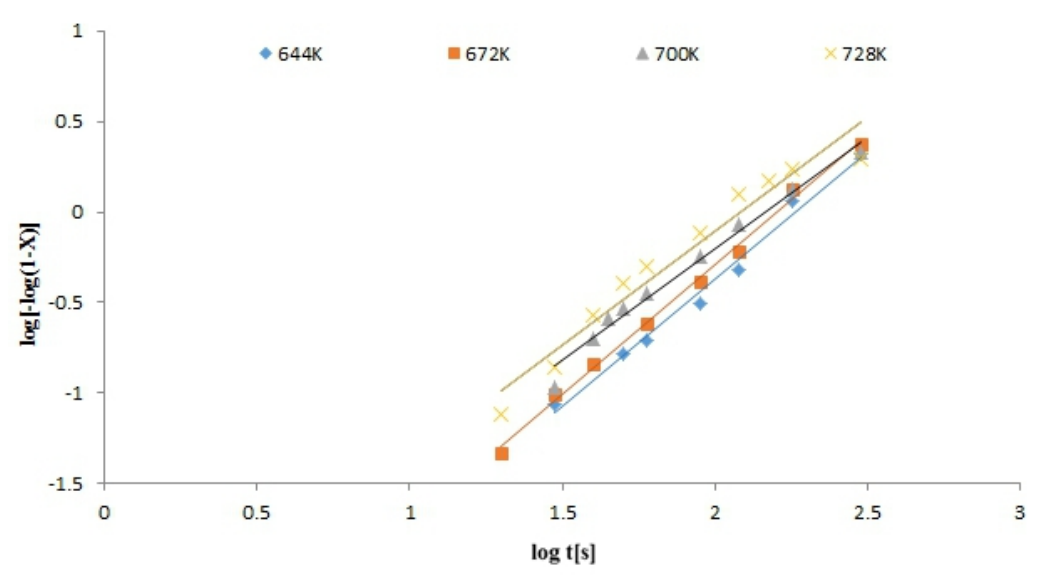

(b)

Fig.7 The plot of " $\log [-\log (1-X)]$ versus " $\log \mathrm{t}(\mathrm{s})$ " for various austempering temperatures : a) $561 \mathrm{~K}, 589 \mathrm{~K}$, and $617 \mathrm{~K}$, b) $644 \mathrm{~K}, 672 \mathrm{~K}, 700 \mathrm{~K}$, and $728 \mathrm{~K}$

The linear regression equations are shown as follows:

$$
\begin{gathered}
Y_{561}=-3.843+1.5629 * \mathrm{X}, R^{2}=0.983 \\
Y_{589}=-3.7384+1.5543 * \mathrm{X}, R^{2}=0.998 \\
Y_{617}=-3.9046+1.6386 * \mathrm{X}, R^{2}=0.995 \\
Y_{644}=-3.1943+1.4117 * \mathrm{X}, R^{2}=0.988 \\
Y_{672}=-3.1674+1.4372 * \mathrm{X}, R^{2}=0.996 \\
Y_{700}=-2.6859+1.2416 * \mathrm{X}, R^{2}=0.983 \\
Y_{728}=-2.6344+1.265 * \mathrm{X}, R^{2}=0.951
\end{gathered}
$$

The " $k$ " and " $n$ " values which are determined from the slopes and intercepts with the $\mathrm{Y}$ axis are listed in Table 2.

Table 2: The values of " $n$ " and " $k$ " for bainite formation

\begin{tabular}{ccc}
\hline Temperature & $\mathrm{n}$ & $\mathrm{k}[1 / s]$ \\
\hline $561 \mathrm{~K}$ & 1.5629 & $5.908 \times 10^{-3}$ \\
\hline $589 \mathrm{~K}$ & 1.5543 & $6.705 \times 10^{-3}$ \\
\hline $617 \mathrm{~K}$ & 1.6386 & $6.868 \times 10^{-3}$ \\
\hline $644 \mathrm{~K}$ & 1.4117 & $9.824 \times 10^{-3}$ \\
\hline $672 \mathrm{~K}$ & 1.4372 & $1.113 \times 10^{-2}$ \\
\hline $700 \mathrm{~K}$ & 1.2416 & $1.339 \times 10^{-2}$ \\
\hline $728 \mathrm{~K}$ & 1.265 & $1.592 \times 10^{-2}$ \\
\hline
\end{tabular}


The minimum energy which allows the atoms to start the chemical reaction is the activation energy. According to the "Arrhenius" equation, the formula of activation energy and specific reaction rate is shown as follows (Milosan, 2008):

$$
\mathrm{K}=\mathrm{A} * e^{-Q / R T}
$$

Where: $\mathrm{K}-$ Rate constant which depends on temperature
A - Reaction frequency factor $[1 / s]$
$\mathrm{R}$ - General gas constant $8.31[\mathrm{~J} / \mathrm{mol} * \mathrm{~K}]$
Q - Activation energy
$\mathrm{T}$ - Temperature $[K]$

To determine the value of $\mathrm{Q}$ and $\mathrm{A}$, the Arrhenius equation can be rewritten (Milosan, 2008):

$\log \mathrm{k}=-\log \mathrm{e} \frac{\mathrm{Q}}{R T}+\log \mathrm{A}$

The relationship between $\log \mathrm{k}$ and $1 / \mathrm{T}$ is shown in Figure 8.

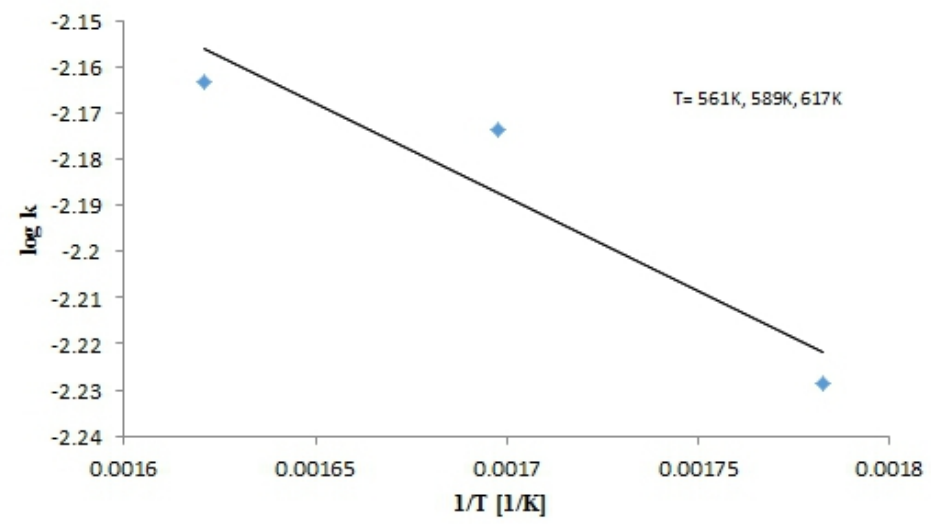

(a)

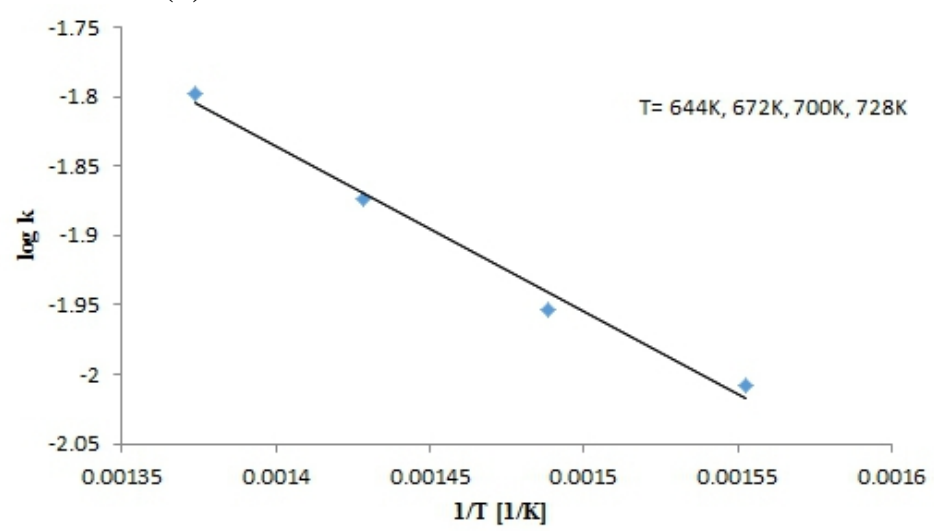

(b)

Fig. 8 The linear relationship between $\log \mathrm{k}$ and 1/T: a) $561 \mathrm{~K}, 589 \mathrm{~K}$, and $617 \mathrm{~K}$, b) $644 \mathrm{~K}$, $672 \mathrm{~K}, 700 \mathrm{~K}$, and $728 \mathrm{~K}$ 
Based on equation 5, the values of $\mathrm{Q}$ (activation energy) and $\mathrm{A}$ (reaction frequency factor) can be determined by the slope of the regression line and intercept with the $\mathrm{Y}$ axis, see Table 3.

Table 3: The values of activation energy $\mathrm{Q}$ and reaction frequency factor $\mathrm{A}$

\begin{tabular}{ccc}
\hline Material & $\mathrm{Q}\left(\frac{\mathrm{J}}{\mathrm{mol}}\right)$ & $\mathrm{A}(1 / \mathrm{s})$ \\
\hline $5160(561 \mathrm{~K}-617 \mathrm{~K})$ & $7.81 \times 10^{3}$ & $3.2 \times 10^{-2}$ \\
\hline $5160(644 \mathrm{~K}-728 \mathrm{~K})$ & $2.26 \times 10^{4}$ & $6.62 \times 10^{-1}$ \\
\hline
\end{tabular}

\section{Conclusion}

The bainite transformation kinetics in 5160 steel with various holding times at different austempering temperatures were studied, the results can be summarized as follows:

(a) Based on the microstructure observation, lower bainite was formed at $561 \mathrm{~K}, 589 \mathrm{~K}$, and $617 \mathrm{~K}$, however, at $672 \mathrm{~K}, 700 \mathrm{~K}$, and $728 \mathrm{~K}$, upper bainite was formed. Two types of bainite: upper bainite and lower bainite were observed at $644 \mathrm{~K}$.

(b) The transformation fraction results show that as the temperature increases, the bainite transformation occurs faster.

(c) The bainite transformation kinetics were determined by the "Avarami" equation and "Arrhenius" equation.

(d) For the range of $561 \mathrm{~K}$ to $617 \mathrm{~K}$ austempering temperatures, the frequency factor is $3.2 \times 10^{-2}(1 / \mathrm{s})$ and the 5160 steel requires an activation energy of $7.81 \times 10^{3} \frac{\mathrm{J}}{\mathrm{mol}}$

(e) From $644 \mathrm{~K}$ to $728 \mathrm{~K}$, the frequency factor is $6.62 \times 10^{-1}(1 / \mathrm{s})$ and the 5160 steel requires an activation energy of $2.26 \times 10^{4} \mathrm{~J} / \mathrm{mol}$

\section{References:}

1. Krishna, P. V., Srikant, R. R., Iqbal, M., \& Sriram, N. (2013). Effect of Austempering and Martempering on the Properties of AISI 52100 Steel. ISRN Tribology,2013, 1-6. doi:10.5402/2013/515484

2. Speer, J. G., Edmonds, D. V., Rizzo, F. C., \& Matlock, D. K. (2004). Partitioning of carbon from supersaturated plates of ferrite, with application to steel processing and fundamentals of the bainite transformation. Current Opinion in Solid State and Materials Science,8(3-4), 219-237. doi:10.1016/j.cossms.2004.09.003

3. Grajcar, A., Zalecki, W., Skrzypczyk, P., Kilarski, A., Kowalski, A., \& Kołodziej, S. (2014). Dilatometric study of phase transformations in advanced high-strength bainitic steel. Journal of Thermal Analysis and Calorimetry, 118(2), 739-748. doi:10.1007/s10973-014-4054-2

4. Borgenstam, A., \& Hillert, M. (2012). Kinetics of bainite transformation in steels. Phase Transformations in Steels,468-501. doi:10.1533/9780857096104.3.468 
5. Durand-Charre, M. (2004). The bainite transformation. Microstructure of Steels and Cast Irons Engineering Materials and Processes, 223237. doi:10.1007/978-3-662-08729-9_12

6. Bhadeshia, H. (1990). Kinetics of the Bainite Transformation. Materials Science Forum,56-58, 263-274. doi:10.4028/www.scientific.net/msf.56-58.263

7. Bhadeshia, H., \& Edmonds, D. (1980). The mechanism of bainite formation in steels. Acta Metallurgica,28(9), 1265-1273. doi:10.1016/0001-6160(80)90082-6

8. Ławrynowicz, Z. (2016). Kinetics of the Bainite Transformation in Austempered Ductile Iron ADI. Advances in Materials Science,16(2). doi:10.1515/adms-2016-0008

9. Takahashi, M. (2004). Recent progress: kinetics of the bainite transformation in steels. Current Opinion in Solid State and Materials Science, 8(3-4), 213-217. doi:10.1016/j.cossms.2004.08.003

10. Soliman, M., \& Palkowski, H. (2016). Development of the low temperature bainite. Archives of Civil and Mechanical Engineering, 16(3), 403-412. doi:10.1016/j.acme.2016.02.007

11. Zhou, M., Xu, G., Tian, J., Hu, H., \& Yuan, Q. (2017). Bainitic Transformation and Properties of Low Carbon Carbide-Free Bainitic Steels with Cr Addition. Metals, 7(7), 263. doi:10.3390/met7070263

12. Krauss G. Steels (1990) Heat treatment and processing principles. Colorado: ASM International.

13. Navarro-López, A., Hidalgo, J., Sietsma, J., \& Santofimia, M. (2017). Characterization of bainitic/martensitic structures formed in isothermal treatments below the $\mathrm{M}$ s temperature. Materials Characterization, 128, 248-256. doi:10.1016/j.matchar.2017.04.007

14. Junior, J. A., \& Santos, D. B. (2013). Effect of tempering temperature on isothermal decomposition product formed below Ms. Journal of Materials Research and Technology,2(2), 93-99. doi:10.1016/j.jmrt.2012.11.001

15. Bhadeshia, H. K. (1992). Bainite in steel. Institute of Materials.

16. Caballero, F. G., Santofimia, M. J., García-Mateo, C., \& Andrés, C. G. (2004). Time-Temperature-Transformation Diagram within the Bainitic Temperature Range in a Medium Carbon Steel. Materials Transactions, 45(12), 3272-3281. doi:10.2320/matertrans.45.3272

17. Quidort, D., \& Brechet, Y. (2001). Isothermal growth kinetics of bainite in $0.5 \%$ C steels. Acta Materialia,49(20), 4161-4170. doi:10.1016/s1359-6454(01)00316-0

18. Tomita, Y., \& Okawa, T. (1993). Effect of microstructure on mechanical properties of isothermally bainite-transformed 300M 
steel. Materials Science and Engineering: A,172(1-2), 145-151. doi:10.1016/0921-5093(93)90434-g

19. Khan, S. A., \& Bhadeshia, H. K. (1990). The bainite transformation in chemically heterogeneous $300 \mathrm{M}$ high-strength steel. Metallurgical Transactions A,21(3), 859-875. doi:10.1007/bf02656570

20. Saeidi, N., \& Ekrami, A. (2009). Comparison of mechanical properties of martensite/ferrite and bainite/ferrite dual phase 4340 steels. Materials Science and Engineering: A,523(1-2), 125-129. doi:10.1016/j.msea.2009.06.057

21. Johnson, D. R., \& Becker, W. T. (1993). Toughness of tempered upper and lower bainitic microstructures in a 4150 steel. Journal of Materials Engineering and Performance,2(2), 255-263. doi:10.1007/bf02660294

22. Milosan, I. (2008). Aspects about the kinetics and thermodynamic transformation of a special S.G. cast iron, $6^{\text {th }}$ international DAAAM Baltic Conference, Industrial Engineering, 24-26 April 2008, Tallinn, Estonia.

23. Ioan, M. (2014). Kinetics of a S.G. cast iron. European Scientific Journal:vol.3, issn: 1857-7881.

24. Umemoto, M., Horiuchi, K., \& Tamura, I. (1982). Transformation Kinetics of Bainite during Isothermal Holding and Continuous Cooling. Transactions of the Iron and Steel Institute of Japan,22(11), 854-861. doi:10.2355/isijinternational1966.22.854

25. Bhadeshia, H. K. (1982). Bainite : Overall Transformation Kinetics. Le Journal de Physique Colloques,43(C4). doi:10.1051/jphyscol:1982468 